\title{
ARTICLE
}

\section{Sustainability and sacred values}

\author{
John Cairns, Jr. \\ Department of Biology, Virginia Polytechnic Institute and State University, Blacksburg, Virginia 24061, USA
}

\begin{abstract}
Successful implementation of the quest for sustainable use of the planet requires that human society both reexamine and expand present views of what is sacred and what is not. The most important aspect will be going beyond a homocentric focus to a biocentric emphasis. A unifying theme would be the desire to leave a habitable planet for human descendants and those of other species. It is unlikely that society can be confident of achieving sustainability until persuasive evidence supporting this belief has existed for several generations. In order for sustainable use of the planet to persist indefinitely, the conditions essential to this state must be morally preserved on sacred grounds. Viewing natural systems as sacred requires not only preventing damage to them but, wherever possible, repairing damage to them caused by humankind.
\end{abstract}

KEY WORDS: Sacred $\cdot$ Biospheric life support system $\cdot$ Coevolution $\cdot$ Sustainability

\section{INTRODUCTION}

A new relationship between humankind and Earth based on a belief that the planet's biospheric life support system is sacred is needed for humanity to create planetary sustainability. A spiritually based biophilia that is attentive to scientific evidence is a central solution to the large-scale environmental problems that beset humanity. This discussion largely, but not entirely, stays within this theme. It is essential that humankind be guided by nature-based cultures that understand the symbiotic relationship between humankind and nature. Starting with the cave painters of Chauvet, Lascaux, and Altamira, humankind depicts, through art, a special relationship with nature that venerates humankind's co-existence and interdependence with the environment, an environment in

*E-mail: cairnsb@vt.edu which subject and object and predator and prey are intrinsically linked as one. Today, in cultures that maintain some vestiges of this relationship with Earth, humankind can, though only distantly, discern a sense of co-evolutionary unity with the surrounding environment.

The mission of this discussion is to persuade people to alter their behaviors and come to an environmental awaking of a co-evolutionary relationship with nature so that species, ecosystems, and humanity can be sustained. How do we make credible the threats we perceive? How do we hold attention? Have we overloaded the reader with anxiety and guilt? What do they know, want, fear, and care about? Is the tempo of injury to the planet a symptom of some deep-seated psychopathology? How do we treat humanity's addiction to technology? How do we establish a balance between people and nature? Why does society persist in destroying its habitat? Movements that fail to consider carefully some of these factors may fail to persuade. To be 
upbeat, when it comes to raising the collective consciousness about liabilities of industrialization and population growth, many scientists and citizens have done a remarkable job at articulating impending risks. The health of the planet is now a major political issue in every industrial society.

'Is it ethical for Homo sapiens to modify the planet so that one species can inhabit it indefinitely when other species are unlikely to have a comparable opportunity?' (Cairns 2002a). In order to achieve sustainable use of the planet, some globally shared ethical values are essential. Although some species have existed for impressive temporal spans, most do not. Successional processes are characteristic of virtually all dynamic, biotic communities (the biota of oceanic thermal vents and other remarkable habitats may have a much lower successional rate due to their uniqueness and harsh conditions). If a single species (Homo sapiens) can expect to exist indefinitely on the planet, it is essential that the goals and conditions for sustainability be widely accepted and implemented. If these goals and conditions are successfully met, sustainability requires that they be secured against violation, infringement, etc. This condition meets one of the dictionary definitions of sacred-sacred things are held in reverence. Another dictionary definition of sacred is 'properly immune from violence, interference, etc.' A sacrilege is the violation or profanation of anything sacred or held sacred. If one accepts these definitions of sacred, then the goals and conditions for a sustainable world become sacred.

\section{THE BIOSPHERIC LIFE SUPPORT SYSTEM}

Homo sapiens has been dependent for its entire existence upon the biospheric (ecological) life support system for both natural capital and ecosystem services (Hawken et al. 1999). Yet the 20th century saw damage to natural systems that was unprecedented in human history (M cNeill 2000). It is abundantly clear that the practices that caused this damage are not sustainable. The primary cause of this damage is society's addiction to exponential economic growth, which is revered and fits one of the definitions of sacred (i.e. secured against violation or infringement), although most people would be reluctant to use the word sacred in this context.

It has often been said that humans protect what they love and love what they understand. However, ecosystems have no easily identified boundaries and are also complex, multivariate systems that are difficult to understand, even for professional ecologists. Of course, charismatic species are loved by many humans who often protect the habitat of that particular species.
However, even in such instances, society has been only marginally successful in even preserving these species.

Arguably, the most persuasive assumption that explains human society's failure to revere nature and to make its integrity sacred is the belief that nature, as Sinsheimer (1978) noted, does not set traps for unwanted species. One of the principal supports for this assumption is the belief of some economists that human society can function without natural resources (e.g. Simon 1981). If humans do not need nature, why view it as inviolate (e.g. sacred)? Further support for failure to revere nature is the belief that humans should dominate nature (White 1967).

\section{SACRED BELIEFS}

Arguably, the present is an age of sacred beliefs rather than sacred places or symbols, although these still play a role. These sacred beliefs often have little to do with organized religion, although they are, on a long-term basis, more matters of faith than robust evidence-we believe what we do not see. Four of the most prominent sacred beliefs follow. (1) Perpetual economic growth is possible on a finite planet and will solve all societal problems as a rising tide lifts all ships. (2) For every societal problem, there is a technologi$\mathrm{cal} /$ economic solution, that is, every problem created by technology will be solved by a new technology for which funds will become available when the marketplace indicates the need for a solution. (3) Humans everywhere should be numerous, wealthy, and in control of the forces of nature (e.g. Kahn et al. 1976). (4) Humans are identified primarily by their material possessions (e.g. Goffman 1961).

The first attribute mentioned to an 'outsider' is growth. Even churches and academic institutions are concerned with growth, as are municipalities, industries, and the like. Up to a point, growth in numbers of individuals does frequently result in economies of size, but eventually diseconomies appear (e.g. Brown 2001). However, society has become accustomed to the momentum of growth and is reluctant to change. In addition, many individuals continue to reap profits since tax burdens, loss of amenities, reduced quality of life, etc. are spread over the entire population, while the major financial benefits continue for a small portion of the population. Hardin's (1968) classic essay on the tragedy of the commons illustrates how the system continues to reward those who ignore the cost to others (and even eventually to themselves). Teune (1988) goes even further by stating that individually based secular morality cannot accept a world without growth. Cairns (2002b) discusses the relationship between 
individual worth and dignity and the integrity of the interdependent web of life. In the absence of an ecological life support system, the individual cannot survive. Alternatively, reduction in quantity and quality of ecosystems will affect both quality of life and the expression of individual worth and dignity. As the situation worsens in each bioregion, the numbers of environmental refugees will increase adversely, affecting or even destabilizing other areas (e.g. Cairns, in press). Exceeding the carrying capacity of natural systems may have severe consequences, essentially ignored by those who favor exponential growth, especially economic growth. Numerous publications discuss the rapid growth of the human population in the last century. Astonishingly, most people consider the present rate of growth to be normal and past rates abnormal. However, the 20th century was, in many ecological respects, an aberration.

The present boom in population growth is the most spectacular in human history and almost certainly neither likely to continue nor to occur again. One of the characteristics of exponential growth is that catastrophe arrives so suddenly that the slowly changing social system cannot adjust. The last few centuries have been remarkably benign climatically for humans. However, severe ecological disequilibrium could easily have consequences that would dwarf those of terrorism, with which some countries have been preoccupied recently. This comparison is not intended to denigrate anti-terrorist activities that, if effective, should reduce human suffering. However, the funds devoted to sustainable use of the planet and protection of the biospheric life support system are not proportional to the comparative risks involved.

Lauber (1978) states that the primary motivation for growth is not the pursuit of material gratification by the masses, but the pursuit of power by elites. The still unfolding ENRON stock scandal in the United States appears to support, at least partly, this assumption. If wealth is associated with power, then the fact that, in the United States, $1 \%$ of the population controls $34.3 \%$ of the wealth supports this conclusion (e.g. DeM arco and Hightower 1988). Durant and Durant (1968, p. 20) state: 'Inequality is not only natural and inborn, it grows with the complexity of civilization.' However, they also conclude (p. 57) that, although the concentration of wealth is natural and inevitable, it is periodically alleviated by violent or partial redistribution. They espouse the view that all economic history is the slow heartbeat of the social organism, a vast systole and diastole of concentrating wealth and compulsive redistribution. This view is a stark contrast to the perpetual exponential growth paradigm that is now the dominant belief globally. Clearly, perpetual economic growth on a finite planet is a social trap (e.g. Costanza
1987) that places both individuals and societies in patterns of behavior with the lure of short-term benefits. These promises may mask long-term costs, which often override the short-term benefits. Sustainability seeks to avoid practices that undermine societal well being and rewards behaviors that produce long-term benefits to both human society and natural systems. Holding such practices inviolate (i.e. sacred) should be one of the pillars of a sustainable society.

\section{COEVOLUTION}

The ecological life support system (the biosphere) consists of an extraordinary web of interrelationships, energy and nutrient flows, and a variety of cyclic events. Although competition receives much attention, mutualistic interactions are critically important to the web's structure and function. Lovelock (1988) hypothesizes that primary evolution occurs at the global level, and individual species evolve within this matrix. Cairns (1994) believes that the coevolution between human society and natural systems can be either hostile (e.g. pests and pesticides) or benign (e.g. ecosystem services benefiting humans). Sagan $\&$ Margulis (1993) speculate that biospheric relations are undergoing a major reorganization because of the distress humans, who are sentient beings, feel because of dysfunctional anthropogenic changes. In contrast, Gadgil (1993) confesses to being a confirmed biophilic, but notes that this trait is not widely shared by kinfolk.

\section{TRANSITION TO A SUSTAINABLE WORLD}

The most desirable transition to a sustainable world is facilitated by a vastly increased ecological literacy. In his superb book, Orr (1992) remarks that 'Natural evolution at the ecosystem level leads toward increasing diversity, ecological complexity, stability, and balance. Left to itself, nature evolves in ways that tend to create systems that are stable over long periods of time within relatively narrow limits.' In contrast, he notes that 'M odern societies seem to have adopted the purpose of growing to their maximum extent. Evolution has equipped humans with no instinct that tells us when enough is enough.' Wilson (2002) makes a statement that is appropriate in this context: 'At the end of the day, in a more democratic world, it will be ethics and desires of the people, not their leaders, who give power to government and the NGOs or take it away. They will decide if there are to be more or fewer (nature) reserves, and choose whether particular species live or die.' I share Wilson's conviction that adequate resources exist to save life on Earth but have 
trouble deciding what will be the primary impetus for a shift in ethical values. One hopes it will be enlightenment, but it may well be a major ecological catastrophe adversely affecting humankind. This major point merits amplification, that is, we may need a 9/11 or ENRON environmental catastrophe to reshape our institutions and refocus our consciousness toward a sustainable ethos. It is amazing how institutional change can rapidly occur under a 9/11 emergency. The question is whether the environmental insults will be contained to allow mid-course correction.

\section{PARADIGM SHIFT}

Anyone well acquainted with the ecological destruction in the world all too often verges on uncontrolled panic, and Leopold was correct in stating that, to be an ecologist, is to live in a world of wounds. It does not require a trained eye to see the wounds, but it takes a moderate level of ecological literacy to appreciate their full gravity. However, only an individual with little or no common sense can entirely avoid the implications for human society, even when oblivious to the fate of other species. Except for the truly masochistic, a few illustrative examples should make the point. Fischetti (2001) describes in persuasive detail not only what will probably happen to N ew Orleans, a Gulf of M exico city that lies below sea level, but what has already happened: e.g. the state of Louisiana (USA) in which $\mathrm{New}$ Orleans is located loses 1 acre of land every 24 minutes. Emergency management personnel have already stored 10000 new 'body bags' for the dead if a disaster occurs. The tiny village of Chesire, West Virginia (population 221), may disappear from the map because, among other factors, the U.S. Center for Disease Control confirmed that the levels of sulfur dioxide and sulfuric acid could be hazardous to human health (Kipling 2002). As a consequence, residents may be forced to vacate their homes. The 11000 inhabitants of the tiny island of Tuvalu must leave because of rising sea levels. The Earth Summit (Rogers 1993) provides an excellent analysis of biodiversity and other problems. Probably the most useful and concise summary of the global environmental condition is Brown's annual State of the World Report (Brown 2002).

The continual statements that there is insufficient evidence of environmental damage are specious. In the first place, the primary burden of proof of damage or lack thereof should be the responsibility of those few who will benefit financially from the proposed action rather than the large number who will pay for any damages resulting from ignorance or deliberate avoidance of responsibility. In the United States, the ENRON scandal is a good illustration of this in the financial world. Many people lost their life savings as well as their retirement benefits while the corporate executives 'retired' with stupendous benefits. ENRON and 9/11 are also timely examples of how we all were enveloped in a false sense of security. Imagine proposing the 9/11 scenario on 9/10 or before. Even Hollywood would have rejected the script as too far fetched. Likewise, if the best Wall Street financiers had been informed that many of blue chip companies were seated in sand before the ENRON debacle, no one would have taken the information seriously. Life is non-linear.

However, there is an even more important point. It is impossible to prove that any situation is 'safe,' like global climate change, especially if it is unprecedented in spatial and temporal scales. This uncertainty requires that all environmental decisions be based primarily on ethical values - a sense of the sacred. I have been a scientist for over half a century and have the highest respect for sound science. However, no amount of sound science can replace ethical value judgments, although the latter should be guided by sound science.

In contrast, from civic leaders of small towns to those with international influence, economic growth is the mantra given with no hesitation or apology. In fact, espousing non-economic values, such as ethics and the sacred, could easily be fatal to a public career since all leaders depend on financial support from a variety of sources that benefit from unrestrained economic growth. Some industries are even environmentally damaging and are still the recipients of substantial government subsidies (e.g. Roodman 1996).

\section{OPTIMISM ABOUT SUSTAINABLE USE OF THE PLANET}

The geological/paleontological record shows that most species have a fatal flaw that ends their time on the ecological stage in the evolutionary theater. Materialism and failure to cherish other life forms may be the fatal flaw of humans that limits the duration of their time on the planet. Learning to live sustainably will extend the time, perhaps for a long period. It will also expand the sense of community with others of the human species and with millions of other species with which humans share the planet. The hope that this vision will be widely shared makes me optimistic about the future.

Berry (2002) expressed his concern about spending his life on 2 losing sides - the causes of agrarianism and conservation, 'despite local victories have suffered an accumulation of losses, some of them probably irreparable - while the third side, that of land-exploit- 
ing corporations, has appeared to grow ever richer.' Berry uses the word appeared because he feels that the wealth of corporations is illusory because their wealth is based not on the resources of nature, which corporations are recklessly destroying, but on fantasy. Berry feels that the dualism of domestic and wild has obscured the absolute dependence of human domesticity upon the wildness that supports it. He feels that domesticity and wildness are intimately connected and what is alien to both is corporate industrialism. Although Berry does not use the words ethics and sacred, it is abundantly clear that both are essential to a mutualistic relationship between humans and wild systems.

Suzuki (1998) uses the word sacred in the title of his book and begins with two critical sentences in the introduction (p. 7): 'These fundamental requirements (for humans - insert mine) are rooted in the Earth and its life-support systems. They are worthy of reverence and respect, that is, they are sacred.' Ehrlich (2000) identifies a crucial relationship between reverence and science- he is convinced that a quasi-religious movement, one concerned with the need to change the values that now govern much of human activity, is essential to the persistence of human civilization. These warnings will be heard once serious environmental non-linear impacts are encountered and accepted. He feels that science, even the science of ecology, cannot answer all questions and that there are 'other ways of knowing' - this concept does not diminish the absolutely critical role that good science must play in saving civilization.

Suzuki and Ehrlich, both scientists, do not reject science but rather view science as a source of information, which will probably make a reverence for Earth's ecological life support system more meaningful. In this context, it is important to remember that information is not knowledge and knowledge is not wisdom. Knowledge is a synthesis of information as Wilson (1998) espouses in Consilience: The Unity of Knowledge. He recounts how the vision that reached its apogee in the Age of Enlightenment was gradually lost due to the increased fragmentation (reductionist science) and specialization of knowledge in the last 2 centuries. Wilson clearly believes in a new age of synthesis, which includes biology and the physical sciences, religion, philosophy, anthropology, and the arts. An enlightened synthesis would almost certainly include all the 'tribal units' now known as the disciplines. The synthesis may likely be instrumental at also understanding environmental problems holistically, problems that involve wide time and space scales and disciplinary integration. At the moment, we have a paucity of synthesis across disciplines on most subjects, environmental and otherwise. The idea of consilience does not denigrate the disciplines, but rather shows how integrating them will provide a new vision of the world and the relationship of humans with other life forms.

Hawken (1993) and Hawken et al. (1999) provide numerous persuasive examples of the ways in which capitalism can flourish and natural capital remain intact. Most important, Hawken et al. (1999, p. 309) point out, in the often acrimonious debate between ecologists and economists, that both sides may be right. Ecologists have robust evidence that the worldwide trend of indicators of ecological health has been downward. Economists also have persuasive evidence of increased human life expectancy, decreased child mortality, improved nutritional intake, and improved standards of living, despite global exponential population increase. The apparently contradictory trends and the heated arguments that ensue are the delight of the news media. However, contradictions can be explained by the concept of overshoot: the ability to exceed Earth's carrying capacity temporarily and put natural systems into decline. Hawken et al. (1999) have a superb metaphor for this situation - the ability to accelerate an automobile that is low on gasoline does not prove that the tank is full. To achieve status or even acceptance in a profession, trade, or any occupation, one must adopt a particular mind set. To achieve sustainable use of the planet, both individuals and societies must transcend a host of mind sets and become eclectic without abandoning any original skills. Becoming eclectic is essential to the vision - the skills are essential to the implementation. This goal seems truly formidable, arguably impossible. If, as LéviStrauss (1968) speculated, human ancestors living 2 or 3 hundred thousand years ago had some minds of the caliber of Plato or Einstein as a group, they were also probably as capable as humans are today. The aggregate skills may now be applied to shopping on the internet or to the patience of acquiring food or to enduring commuter traffic delays, but they can be redirected, especially if rampant consumerism is reduced (e.g. Durning 1992, Levering \& Urbanska 1992).

\section{THE SACRED EARTH}

For me, a major shock followed the release of 'World Scientists' Warning to Humanity' by the Union of Concerned Scientists (1992). More than 1600 scientists from 71 countries signed the document. All were senior scientists, and the total included over half of all the living recipients of the Nobel Prize. The document began by stating that human beings and the natural world are on a collision course, then noted the harsh and often irreversible damage to the environment and 
critical resources caused by human activities. The document concluded that a vast change is needed in humankind's stewardship of Earth and all life on it if vast human misery is to be avoided and the planet is to be saved from irretrievable mutilation. As one of the scientists who signed the document, I eagerly awaited the media response and was prepared to answer questions from the local news media and colleagues. Nothing happened; I was stunned. M eanwhile, the ecologically destructive course continued unchanged. It is noteworthy that, after $9 / 11$, journalists researched those authors and analysts that forewarned of impending risks from homeland terrorism. Airport security vulnerability reports have resurfaced and authors are receiving spotlight attention. Viewing humankind as part of a larger living system should expand the range of compassion for all life forms, both temporally and spatially. The Union of Concerned Scientists expressed it well:

As scientists, many of us have had profound experiences of awe and reverence before the universe. We understand that what is regarded as sacred is more likely to be treated with care and respect. Our planetary home should be so regarded. Efforts to safeguard and cherish the environment need to be infused with a vision of the sacred.

All humankind, not just scientists, should embrace this view.

\section{ACTION OR INACTION?}

Cairns (1994) describes 2 relationships between human society and natural systems. The accepted practice in the 20th century was to dominate nature (i.e. developing pesticides, clear cutting forests, damming rivers, etc.). At the same time, nature evades human domination by such techniques as evolving pesticide and drug resistant organisms; invading human settlements with cockroaches, rats, and whitetail deer; and proliferating exotic species. The activities of humankind should be subjected to ethical analysis (i.e. eco-ethics) to determine what values (including the sacred) are damaged or strengthened by particular policies and practices. Both ecosystems and human social systems are dynamic and so must be the relationship between them. Katz (2000) believes in a dualism of human artifacts and natural entities and argues (Katz 1997) that ecological restoration of damaged ecosystems (and to a certain extent, policies of natural resource management) do not actually restore or manage natural systems. Katz believes that, once a system has been created, designed, or managed by human technology and science, it is no longer a natural system, but rather an artifact resulting from human intervention and design. The National Research Council (1992) recognized the difficulty of replicating nature as follows: 'In this report, restoration is defined as the return of an ecosystem to a close approximation of its condition prior to disturbance. In restoration, ecological damage to the resource is repaired.'

Ecological restoration has been introduced at this point because restoration is the best way humankind can make reparations for the enormous ecological damage it has caused. If the result is a self-maintaining ecosystem, ecological dynamics will ensure that the restored ecosystem will develop its own integrity, structure, and function. It will then eventually be 'natural' - even if human intervention is essential to reactivate natural processes. Five major, global extinctions have occurred, and humans have regarded what emerged as natural. After each extinction, dramatic changes occurred in types of species, but the ecosystem dynamics were probably rather similar, even though the ecosystems did not look alike. Natural systems can survive without humans - after all, they did so for most of the time that life has been on Earth! However, far less evidence supports the idea that humans can continue to exist without a mutualistic relationship with nature. Who doubts that, if humankind were to commit ecological suicide, the remaining species would evolve new and different life forms over evolutionary time (e.g. Gould 1998)? What is the probability that some of the $30+$ million species on Earth will survive an extinction driven by activities of humankind? Most ecotoxicologists would affirm that, even if humans drive many more species to extinction, enough would remain to tolerate the changed conditions to rediversify over evolutionary time. As Wilson (1992) remarks, although nature is violent, life is resilient. Therefore, a spirit of stewardship that enhances (rather than diminishes) biodiversity, has reverence for life, and holds Earth sacred is not 'faking nature,' even if the restored systems do not initially duplicate self-maintaining natural systems. Evolutionary dynamics will recreate natural systems whatever humankind does, however distasteful it may be, over the 21st century or beyond. Assisting nature rather than damaging it is an expression of reverence rather than an attempt to delude humankind. Therefore, I find Katz's (2000) views and the somewhat similar views of Elliot $(1982,1997)$ non-persuasive. Katz (2000) does believe that humanity and nature exist in an interdependent relationship. If one accepts his assertion, the major question is: which actions of humankind are ethical and which components are unethical in this relationship? Enlightened ecological restoration to improve biodiversity and restore ecosystem dynamics is ethical (pertaining to right and wrong in conduct) and biotic impoverishment is unethical. If 
the relationship (a connection, association, or involvement) is guided by eco-ethics, it seems perfectly acceptable.

\section{IMPORTANT ETHICAL QUESTIONS}

The most common questions people ask about the environment concern how long a resource will last, how many humans the planet can hold, etc. Even for questions thus phrased, no simple, direct, persuasive answer surfaces. However, phrasing the questions so that the ethical values become more evident ensures that the response will not only be more complex but also more realistic. Some illustrative examples follow. (1) How many humans should be on the planet if one wishes them to have a quality life, including a mutualistic relationship with natural systems? It took approximately 2 million years for the planet's human population to reach 1 billion. The 5th billion was added in 12 years. Clearly, this rate of increase is neither sustainable nor likely to result in a quality life. Malthus raised the question of human population size over 200 years ago and has been denounced for 2 centuries. More recently, Cohen (1995) addressed the very complex question of how many people Earth can support but not the eco-ethical question of how many people should Earth support. His book, though excellent, does not address either the 'how' or the 'should' question. Post reviews confirm this oversight, and he himself admitted this major shortcoming to a richly researched piece of work.

(2) How long can the human population be sustained if humankind chooses to lead an eco-ethical life style? In the United States just after the middle of the 20th century, there was a fad among college students of seeing how many of them could be crammed into a pay telephone booth (these were small enclosures, now nearly extinct, to protect telephone customers from inclement weather and to provide a small degree of privacy). The numbers were startling and received much attention from the news media. The practice was sustainable for only minutes at the most, and the 'quality of life' was not a long-term consideration. Later, the telephone booth was replaced with the Volkswagen 'Beetle' with similar results. Of course, neither had much effect upon ecosystems. However, from an ecoethical perspective, what can be done with human population density is clearly not what should be done! (3) How much space should be set aside for the primary use of the over 30 million fellow species with which humans share the planet? This important ecoethical question involves ethos, compassion, equity, and fairness. Should humankind act as if it were the only important species on the planet? If not, how much of Earth, land, and water should be left for the more than 30 million other life forms? Also, should quality be a factor? Wildlands (and water) should not be areas that are unattractive to humans, but areas fitting the needs of other species. Since some species require large areas in order to have self-maintaining populations with a viable gene pool, the areas will have to be selected accordingly. How will human access to wild areas be controlled? What will the buffer zones between wild areas and human occupied areas look like? And, of course, the ultimate eco-ethical question: what percentage of Earth should be devoted to other life forms $-10,20,30 \%$, or even as much as $50 \%$ ? The latter Fig. seems large but, at $10 \%$ for other species and $90 \%$ for humans, Earth would be quite similar to animal 'feed lots' where the density is so great that living conditions are barely adequate. In order for these areas set aside for other species to function successfully in the long term, they would have to be regarded as inviolate, i.e. sacred. One does not drill for oil on sacred land or build a dam on it to satisfy short-term perceived human needs. For those who believe that humans are not resource limited (e.g. Simon 1981), this dedication of large parts of Earth to occupancy by other species should pose no problems. Human ingenuity will always find a substitute for scarce resources. For those who believe humans are resource limited, resolving these issues ethically will require much thought and discussion. Sustainable use of the planet requires not only discussion but also sound decisions and implementation of them.

(4) Who should decide which areas are sacred and who should protect them? Ideally, the people who live closest to the areas should make this decision. However, in many Third World countries, forested nature preserves are disappearing one tree at a time at the hands of people who need fuel. Often the exploiters are relatives of those persons employed to protect the forest. Some species are being driven to extinction by those hunters who sell 'bush meat' to poor people. Other species fall victim to poachers who invade nature preserves to harvest body parts of animals thought to increase virility or other attributes in humans. Finally, a large illegal market exists for exotic animals to be pets. Powerful taboos would be necessary to stop or greatly diminish these practices. For migratory species, local control is inadequate unless protection extends to all parts of the migratory system. Globalization has assisted the immigration to and colonization of areas previously inaccessible to many species. If these species are exotics, they are capable of causing major ecological disturbance, even disequilibrium in the areas they manage to colonize. Once established, they are difficult, arguably impossible, to eradicate, as noted in the examples of the rabbit in 
Australia and kudzu vine in the United States. There is abundant literature on this subject, but usually no inexpensive, effective means of control or elimination. Clearly, both local and global identification and protection of sacred areas are essential.

(5) What is the role of each individual with respect to the interdependent web of life? Cairns (2002b) asserts that, if humans acknowledge a dependence on Earth's biospheric life support system (the interdependent web of life) or, at a minimum, a respect for the interdependent web of life, it seems reasonable to judge the inherent worth of an individual in the context of the individual's relationship with the interdependent web of life. Is it a destructive or constructive relationship? If destructive, one might acknowledge 'potential worth,' but there should be persuasive evidence supporting a characterization of 'actual worth.' Most individuals require good conditions to achieve inherent worth. Assessment of dignity is more elusive. But, if dignity is defined as 'bearing, conduct, or speech indicative of self-respect or appreciation of the formality or gravity of an occasion or situation,' it is difficult to visualize how a person lacking a strong sense of eco-ethics could qualify. It is equally difficult to visualize how sustainable use of the planet will be achieved without a strong sense of eco-ethics.

(6) How can renewable natural resources remain inviolate (sacred) if they are depleted faster than the natural rates at which they renew themselves? The answer to this question seems so obvious that it verges on the platitudinous but, since humankind has failed to follow the use of these resources at rates equal to or less than the natural rate of regeneration, it is worth restating.

(7) Can either development or growth, as presently understood, continue indefinitely? If not, is it ethical to continue to use these words in conjunction with the word sustainable (as in sustainable development and sustainable growth or its variant 'smart growth')? Development is usually defined as the process of developing growth. Since sustainable development and sustainable growth (or 'smart growth') are often used as if they were interchangeable, this definition is almost certainly what is intended. Growth usually means to get larger and is often used as the first descriptor of various organizations, from industry to churches. Economic growth is a major objective of most of the planet's economies. But, if something were viewed as sacred, would one want it to be developed? Brown (1978) calculated that, if the planet's human population continued to increase at the annual rate of $2 \%$, then in 2000 years Earth would be a solid mass of people. Yet, many of the world's present leaders regard a $2 \%$ economic growth rate as unacceptable (too small) and most are unwilling to address stabiliz- ing the human population. Nevertheless, a $2 \%$ growth rate means the human population will double in 35 years. Surely the only planet in the solar system that is capable of supporting human life and millions of other life forms should be considered sacred (inviolate). Most would agree that major areas should be 'humanized,' but surely eco-ethics requires that those areas allocated to 'wild systems' be larger than they now are and treated with more reverence.

\section{CONCLUSIONS AND SPECULATIONS}

Archeologists the world over have revealed unmistakable signs of the ecological collapse of ancient civilizations. One cannot help but speculate that these were societies where eco-ethics did not prevail. It also seems quite likely that evidence of unsustainable practices was evident to all but the most casual observers. The belief that humankind has always triumphed over adversity in the past and will continue to do so in the future is not supported by the historic record. The human species has survived, but the loss of human life and degree of suffering must have been as unthinkable to those then alive as an overshoot in carrying capacity is today. If this situation is the case, then the fate of humans is no different than that of any species that exceeds its carrying capacity. If so, then human intelligence, as defined at present, does not seem to provide as much survival value as one would expect. If reason prevails, some of the numerous warning signs will get more attention than they now do. The wise approach to sustainable use, without abuse, of the planet is almost certainly a combination of eco-ethics and all of the scientific, social, and economic information that will make implementation effective. The major determinant should be eco-ethics because sustainability is basically an interlocking, interactive series of value judgments. Arguably, only ethics will restrain human demands upon the planet's natural capital and ecological life support system. A common belief seems to be that, however severe the environmental crisis, it is possible to return to the pre-crisis condition. This return may well be possible if the overshoot in exceeding carrying capacity is modest, quickly discovered, and within the resilience of natural systems. If not, it is highly probable that there will be an extended period of ecological disequilibrium and, when conditions reach dynamic stability, they will be markedly different than the present equilibrium state. The new conditions will probably be less favorable to humankind than the conditions that favored the human species for a huge span of time.

As the first draft of this manuscript is being completed, it is possible to visualize that the worst possi- 
ble situations could happen - a nuclear exchange between India and Pakistan, leading to a wider and even more devastating war. In contrast, it is possible that preliminary steps could be taken to increase the probability of achieving sustainable use of the planet. It has been said that exceptional political leadership can only emerge in a time of crisis. Perhaps in the sustainability crisis, ethical and spiritual leadership will emerge.

\section{ADDENDUM: USEFUL LITERATURE, COMMENTARY, AND RECOMMENDATIONS}

To paraphrase Cairns (1997), when cause and effect relationships are obscure and uncertain, we are less likely to be motivated to action. Operant learning is unlikely to change global behavior relevant to environmental issues.

The following books represent an interesting mixture of ethical values and science. All have a reverence for life and believe Earth is sacred (should not be violated). They are not listed in any order.

The Sacred Balance (Suzuki 1998) is a superb expression of an environmental ethic - finding peace with Earth. Wisdom of the Elders (Suzuki and Knudtson's 1992) provides a collection of readings that give the profound ecological wisdom of a variety of indigenous peoples through their sacred stories. They illustrate the world view in which parts and processes of the universe are holy and are in marked contrast to the economic development mantra so characteristic of the present. The spiritual dimension is, however, not disconnected from ordinary life.

Earth in Mind (Orr 1994) has the unifying theme that the environmental crisis originated from the inability to think about ecological patterns, systems of causation, and the long-term effects of human actions. Orr believes that educators must become students of the ecologically proficient mind and of the practices that must be developed to foster such minds. He bluntly states that this necessity will require the redesign of education itself. A telling point is that the people who have lived sustainably on the planet for any length of time did not have texts describing how to live sustainably-education is no guarantee of ecological decency, prudence, or wisdom. He concludes that what needs to be expressed is an affinity for life.

The Wooing of Earth (Dubos 1980) uses a word seldom seen these days. Woo means to court or to seek the favor, affection, or love of. This book is in sharp contrast to the publications of Katz and Elliot discussed earlier. Dubos believes that humans can improve on nature as well as correct environmental damage by deliberate social action. He further acknowledges that the 'humanization' of wilderness has been achieved at great ecological cost. Dubos concludes that ecological management can be effective only if it takes into consideration the visceral and spiritual values that link humans to Earth.

Man's Responsibility for Nature (Passmore 1974) examines Western traditions and ecological problems. Passmore asks what the West has to jettison and what it has to retain if it is to have any prospect of solving the problems that confront it.

One of the pioneering books in this area is In Defense of Earth (Caldwell 1972). It has taken 3 decades for most of the concepts in this book to become accepted by even a substantial minority, and many are still indifferent to the ideas in this book and many are violently opposed to them. Caldwell's dedication is as timely today as when the book was published: 'To the men and women in many countries and in many organizations who must succeed in their efforts to obtain a sustainable relationship between man and Earth if the human experiment is to continue.' Notice the warning that, unless the relationship changes for the better, humankind may not persist on the planet.

A Global Ethic for Global Politics and Economics (Küng 1998) translated into English from the German original discusses the lack of universal values and the replacement of ideas with specialized interests. This book emphasizes ethics and many topics relevant to the issues in this article.

Let the Mountains Talk, Let the Rivers Run: A Call to Those Who Would Save the Earth (Brower 1995) successfully communicates a reverence for nature to large numbers of individuals. Brower has been called the 'archdruid' of modern environmentalism. He does not hesitate to discuss his mistakes, but, more important, he never lost hope! In 1995, Brower sent me a copy of his book inscribed: 'Persevere!' A good message for all of us who believe in eco-ethics!

Wild Minds (Hauser 2000) is a 'good read' for those who would like to know what is happening in the minds of their fellow species. Some understanding is a must for the complex mental operations of the animal mind that enables it to adapt to the complex niches with which it is associated. This book couples sound science with humor.

The next 3 titles address the interfaces between many parts of society and natural systems:

Mid-course Correction (Anderson 1998) is particularly important because it was written by the CEO of one of the world's largest interior furnishings companies and, therefore, unlikely to be dismissed by other corporate executives. Anderson's quest is first to become sustainable and then to become restorative; he wants to sustain and protect Earth. The already cited 
book Natural Capitalism (Hawken et al. 1999) has similar goals (both were influenced by the Natural Step Program), but it is so different that both should be read. Although the word sacred is not used, both books clearly intend to maintain the integrity of natural systems and feel they should be inviolate (used but not abused). It is worth noting that Hawken was a founder of the Smith Public Broadcasting Services series Growing a Business.

Sustainable Development: Rules of the Game (Roy F. Weston 1995) is really a booklet, but an extremely important one. Roy F. Weston, Inc. is a prestigious international consulting firm specializing in environmental solutions for industry. It notes that, to achieve sustainability, corporations need to emulate the economics of nature as the straightest path to making sustainability work. Nature is described as the quintessential supply sider, with its resources not readily available on demand. Through systematic recycling and reuse, nature does not push its inventory of renewable and nonrenewable resources beyond critical limits for sustainability. In short, there is respect and reverence for the machinery of nature (as Ehrlich 1986 has described it).

The Natural Step for Business: Wealth, Ecology and the Evolutionary Corporation (Nattrass \& Altomare 1999) is an outgrowth of the Natural Step Program pioneered by Dr. Karl-Henrik Robert, who sees humankind running into a funnel of declining life - sustaining resources and increasing demands upon them. Again, he espouses a reverence for natural systems and a desire to preserve their integrity.

The last 4 books illustrate the possibility of a mutualistic interface between humankind and the natural systems of which it is a part:

Striking a Balance: Improving Stewardship of Marine Areas (National Research Council 1997) had among its objectives some alternative models for the governance of marine areas. An important point in the context of this book is the listing of the characteristics of traditional bureaucracies and describing organizational alternatives that would better preserve and protect marine ecosystem integrity.

The New Economy of Nature: The Quest to Make Conservation Profitable (Daily \& Ellison 2002) uses case histories and stories to illustrate the dynamic interplay of science, economics, business, and politics necessary for achieving a basis for sound conservation of natural resources.

Arguably, the most promising harbinger of change is Human Natures (Ehrlich 2000). It is a typical Ehrlich publication with a huge number of eclectic references. The critical issue (on p. 330) is: 'Our challenge is to learn to deal sensibly with both nature and our natures - for all of us to learn to be both environmentalists and "people people."' Ehrlich is fully aware of the basic problem (also on p. 330):

So here we are, small-group animals trying to live, with increasingly rare exceptions, in gigantic groups - trying to maintain health, happiness, and a feeling of connectedness in an increasingly impersonal world in which individual natures are based on ever smaller fractions of society's culture.

Ehrlich has beautifully identified a very crucial issue - namely, how should human natures enhance connectiveness within the species and to the interdependent web of life of which they are a part? Ehrlich remains optimistic about what could be done but, with good reason, pessimistic about what will be done.

Finally, Cairns (2002c) examines Goals and Conditions for a Sustainable World, a collection of essays, mostly from peer-reviewed scientific journals, on the quest for sustainable use of the planet, which is just beginning and is immensely complicated. Humankind will not know that it 'got it right' until there is robust evidence of sustainability.

I frequently get asked why I do not write a simple, straightforward article about sustainability that could be quickly and easily understood. H. L. Mencken had a devastating response to such requests - 'for every complex problem there is a simple direct solution and it is invariably wrong.' Of course, the quest for broad generalities and unifying themes is essential, but it is impossible to resolve any complex problem without a substantial level of literacy. No simple, easy formula exists for improving the long-term situation, but there is an abundance of measures to eliminate clearly unsustainable practices. One could start by determining the size of the ecological footprint (e.g. Wackernagel \& Rees 1996) for one's nation, one's region, or oneself. Or one could read about individual journeys into awareness for conserving Earth's natural resources (e.g. Rohe 2002). Or one could get a variety of views on the social and economic dimensions of sustainability. Although the titles of the individual essays rarely mention it, a definite undercurrent of reverence for natural systems persists in a significant number of essays.

Among the books I found helpful for a broad perspective, Something New Under the Sun: An Environmental History of the Twentieth-Century World ( $M$ cN eill 2000) is worth reading and re-reading. It documents how humankind has crossed threshold after threshold all too often, resulting in a non-linear response that swiftly produced undesirable, unanticipated effects. For example, incremental increases in fishing efforts resulted in a collapse of some oceanic fisheries. Since humankind continues many unsustainable practices, and even subsidizes and extols them, there is a significant probability that more, and proba- 
bly bigger, ecological problems will be encountered in the 21st century. A prudent society would prefer to take precautionary action. As M cNeill notes, many of the ecological buffers (e.g. open land, 'unused' water, unpolluted areas) that aided humankind in difficult times in the past are now largely gone.

GeoDestinies (Youngquist 1997) beautifully illustrates the degree of control Earth's resources have over humankind, such as the degree to which oil has controlled and shaped human society. The exhaustion of natural resources will probably have an equally profound effect. Youngquist clearly does not believe that crucial resources will be as quickly replaced as some economists think. For example, economist Julian Simon (1981) states that even the total weight of Earth is not a theoretical limit to the supply of copper available to humankind; rather, the total weight of the universe would be the theoretical limit. Youngquist believes that the omnipotence of science and technology is a myth. Moreover, the United States and other industrial nations have paid to retain access to Persian Gulf oil, which is about half the world's supply. A notable section of Youngquists' book is devoted to the Gulf War, a response to Iraq's invasion of Kuwait. Ultimately, 660000 military troops from 28 nations freed Kuwait and protected Saudi Arabia at a huge expenditure of manpower and material. The environmental terrorism of Saddam Hussein of Iraq was particularly notable in the Gulf War because he set Kuwait's oil wells on fire; however, the Iraqi retreat was so rapid that not all wells could be blown up or set afire. Enough were burned to turn the sky black, and an estimated 4.6 million barrels of oil were burning each day (Hobbs \& Radke 1992, Hawley 1992), with much, farreaching environmental damage (e.g., Camby 1991 Earle 1992, El-Bay 1992). These resource wars and environmental terrorism deserve careful attention because they may well be harbingers of the future. Clearly, Saddam Hussein, as well as the coalition led by the United States, did not believe that resources were infinitely substitutable. Worse yet, if Hussein could not have them, no one else was going to eitherhence the fires. Most of the calculations of resource availability and how many people they will support do not include acts such as these.

Encompassing Nature (Torrance 1998) is a daunting book best read in small sections, each followed by a period of reflection. The underlying message is quite straightforward: (1) Cultures of the not too distant past had a far more intimate relationship with the world and commonly included rivers and mountains, clouds, rainbows, thunderbolts, sun, moon, and stars among the living things such as plants and animals. (2) Around the turn of the 19th century, nature writers were deeply troubled by humankind's separation from the natural world. This realization was often accompanied by an intense longing for a reconnection with the natural world. In short, the 'holistic' world of creatures, rocks, rivers, and stars had no existence in isolation from the human and divine. (3) A tendency appeared, in at least some civilizations, for cosmogenic myths to be accompanied by religious or metaphysical reflection on the world and humankind's place within it. (4) At present, there is a dichotomy of nature and culture. (5) No single literacy genre encompasses writing about nature throughout the ages, since such a genre could no more be isolated from the myths, hymns and songs, epics and dramas, religious scriptures, and philosophical or scientific treatises that make up the classics of literature than the experience of the extrahuman world can be isolated from our humanity. (6) No sane person will minimize the gravity of the threat, or the urgent need to combat it, by conservation, reduction of pollution, population control, and wiser use of resources.

The book also includes some sections in which the 'archaic' cosmology (in which the whole Earth was considered to be sacred) is given prominent attention. The introduction, from which the above points were obtained, is an essential guide to the organization of the components. The information is difficult to synthesize, but this itself is an important issue since it illustrates how difficult it will be to reach a global consensus on sustainable use of the planet. If Earth is not regarded as sacred and there is much uncertainty in the sciences, how will any unifying theme emerge? The probability is that one or more environmental catastrophes, with large spatial and temporal spans, will be required for the emergence of a new paradigm regarding the need for a mutualistic relationship between humankind and natural systems. This emergence is likely to be hindered by resource wars and the inability of the world's leaders to implement a longterm perspective on both the human and environmental condition.

Acknowledgements. I am indebted to Darla Donald, my editorial assistant, for transferring the handwritten draft of this manuscript to the word processor and for incorporating the changes in subsequent drafts. I thank Charles A. Kennedy, Peter Leigh, and Rudi Gelsey for very useful comments on the first draft. The Willows, Kroontje Health Care Center, kindly provided desk space so that I could work on the 4th draft of this manuscript. The Cairns Foundation paid for the processing costs.

\section{LITERATURE CITED}

Anderson RC (1998) M id-course correction: toward a sustainable enterprise: the interface model. Peregrinzilla Press, Atlanta, GA 
Berry W (2002) For love of the land. Sierra Mag May/J une:50-55

Brower DR (with S Chappel) (1995) Let the mountains talk, let the rivers run: a call to those who would save the earth. HarperCollins Publishers, New York

Brown H (1978) The human future revisited: the world predicament and possible solutions. WW Norton, New York

Brown LR (2001). Eco-economy. WW N orton, New York

Brown LR (2002) State of the world 2002. WW Norton, New York

Cairns J rJ (1994) Ecological restoration: re-examining human society's relationship with natural systems. The Abel Wolman Distinguished Lecture. National Academy of Sciences Press, Washington DC

Cairns J r J (1997). Commentary: defining goals and conditions for a sustainable world. Environ Health Persp 105(11):1164-1170

Cairns J r J (2002a) Preface of goals and conditions for a sustainable world. Ethics Sci Environ Politics, www.esep.de/ journals/esep/esepbooks.html

Cairns J rJ (2002b) Reexamining 'the inherent worth and dignity of every person' paradigm in an interdependent web of life context. J Lib Rel 3(1): www.meadville.edu/ cairns_3_1.html

Cairns J r J (2002c) Goals and conditions for a sustainable world. Ethics Sci Environ Politics, www.esep.de/ journals/esep/esepbooks.cairnsesepbook. pdf

Cairns J r J (In press) Environmental refugees. The Social Contract.

Caldwell LK (1972) In defense of earth: international protection of the biosphere. Indiana University Press, Bloomington, IN

Camby TY (1991). After the storm. Nat Geogr Mag August:2-33

Cohen JE (1995) How many people can the earth support? WW N orton, New York

Costanza R (1987) Social traps and environmental policy. BioScience 37(6):407-412

Daily GC, Ellison K (2002). The new economy of nature: the quest to make conservation profitable. Island Press, Washington, DC

DeMarco S, Hightower J (1988). You've got to spread it around. M other J ones M ay:33

Dubos R (1980) The wooing of earth. Charles Scribner's Sons, New York

Durant W, Durant A (1968) The lessons of history. MJ F Books, New York

Durning AT (1992) How much is enough? WW Norton, New York

Earle SA (1992) Persian Gulf pollution: assessing the damage one year later. Nat Geogr M ag February:122-134

Ehrlich PR (1986) The machinery of nature. Simon and Schuster, New York

Ehrlich PR (2000) Human natures. Island Press, Washington, DC

El-Bay T (1992) The war for oil: effects on land, air, and sea. Geotimes M ay:13-15

Elliott R (1982) Faking nature. Inquiry 25:81-93

Elliott R (1997) Faking nature: the ethics of environmental restoration. Routledge, London

Fischetti M (2001) Drowning New Orleans. Sci Am October:78-85

Gadgil M (1993) Of life and artifacts. In: Kellert SR, Wilson EO (ed) The biophilia hypothesis. Island Press, Washington, DC, p 365-377

Goffman E (1961) Asylums. Doubleday, New York
Gould SJ (1998) Wonderful Life. Replica Books, Bridgewater, NJ

Hardin G (1968) The tragedy of the commons. Science 162:1243-1248

Hauser MD (2000) Wild minds. Henry Holt and Company, New York

Hawken P (1993) The ecology of commerce: a declaration of sustainability. Harper Collins, New York

Hawken P, Lovins A, Lovins H (1999) Natural capitalism: creating the next industrial revolution. Little, Brown, New York

Hawley TM (1992) Against the fires of hell: the environmental disaster of the Gulf War. Harcourt Brace J avanovich, New York

Hobbs PV, Radke LF (1992) Airborne studies of the smoke from the Kuwait oil fires. Science 256:987-991

Kahn H, Brown W, Martel L (1976) The next two hundred years. HarperTrade, New York

Katz E (1997) Nature as subject: human obligation and natural community. Rowman and Littlefield, Lanham, MD

Katz E (2000) A nother look at restoration: technology and artificial nature. In: Gobster PH, Hull RB (ed) Restoring nature. Island Press, Washington, DC, p 37-48

Kipling K (2002) Power play: AEP buys Ohio town. New River Free Press 20(4):1, 6

Küng H (1998) A global ethic for global politics and economics. Oxford University Press, New York

Lauber V (1978) Ecology, politics and liberal democracy. Gov Opposition 13(2):200

Levering F, Urbanska W (1992) Simple living. Penguin Books, Harmondsworth, Middlesex, England

Lévi-Strauss C (1968) The concept of primitiveness. In: Lee $\mathrm{RB}$, de Vore I (ed) Man the hunter. Aldine Press, Hawthorne, New York

Lovelock J (1988) The ages of Gaia. WW Norton, New York

M cNeill J R (2000) Something new under the sun: an environmental history of the twentieth-century world. WW Norton, London

National Research Council (1992) Restoration of aquatic ecosystems. National Academy Press, Washington, DC

National Research Council (1997) Striking a balance: improving stewardship of marine areas.

National Academy Press, Washington, DC

Natrass B, Altomare M (1999) The natural step for business: wealth, ecology and the evolutionary corporation. New Society Publishers, Gabriola Island, British Columbia, Canada

Orr DW (1992) Ecological literacy: education and the transition to a postmodern world. State University Press of New York, Albany

Orr DW (1994) Earth in mind: on education, environment, and the human prospect. Island Press, Washington, DC

Passmore J (1974) Man's responsibility for nature. Charles Scribner's Sons, New York

Rogers A (1993) The earth summit: a planetary reckoning. Global View Press, Los Angeles, CA

Rohe JE (2002) Mary Lou and J ohn Tanton: a journey into American conservation. FAIR Horizon Press, Washington, DC

Roodman DM (1996) Paying the piper: subsidies, politics, and the environment. Worldwatch Institute, Washington, DC

Sagan D, Margulis L (1993) God, gaia and biophilia. In: Kellert SR, Wilson EO (ed) The biophilia hypothesis. Island Press, Washington, DC, p 345-364

Simon J (1981) The ultimate resource. Princeton University Press, Princeton, NJ

Sinsheimer R (1978) The presumptions of science. Daedalus Spring:23-35 
Suzuki D (with A McConnell) (1998) The sacred balance: rediscovering our place in nature. Prometheus Books, Amherst, New York

Suzuki D, Knudtson P (1992) Wisdom of the elders: honoring sacred native visions of nature. Bantum Books, New York

Teune H (1988) Growth. Sage Publication, Inc., Thousand Oaks, CA

Torrance RM (ed) (1998) Encompassing nature: a sourcebook: nature and culture from ancient times to the modern world. Counterpoint, Washington, DC

Union of Concerned Scientists (1992) Preserving and cherishing the arth: an appeal for joint commitment in science and religion. Cambridge, $\mathrm{MA}$

Wackernagel M, Rees W (1996) Our ecological footprint:

Editorial responsibility: Otto Kinne, Managing Editor,

Oldendorf/Luhe, Germany reducing human impact on the earth. New Society, Gabriola Island, B.C., Canada

Weston (1995) Sustainable development: the rules of the game. Roy F. Weston, Inc., West Chester, PA

White L J r (1967) The historical roots of our ecologic crisis. Science 155:1203-1207

Wilson EO (1992) The diversity of life. Harvard University Press, Cambridge, MA

Wilson EO (1998) Consilience: the unity of knowledge. Random House, New York

Wilson EO (2002) The future of life. Alfred A. Knoff, New York

Youngquist W (1997) GeoDestinies: the inevitable control of earth's resources over nations and individuals. National Book, Portland, OR

Submitted: September 9, 2002; Accepted: September 10, 2002 Published on the web: September 13, 2002 